\title{
How Political Parties, Rather than Member-States, Are Building the European Union
}

\author{
Josep M. Colomer \\ Higher Council of Scientific Research (CSIC) and Pompeu Fabra University, Barcelona
}

\begin{abstract}
$\underline{\text { Abstract }}$
Political party formation and coalition building in the European Parliament is being a driving force for making governance of the highly pluralistic European Union relatively effective and consensual. In spite of successive enlargements and the very high number of electoral parties obtaining representation in the European Union institutions, the number of effective European Political Groups in the European Parliament has decreased from the first direct election in 1979 to the fifth in 1999. The formal analysis of national party ${ }^{1}$ s voting power in different European party configurations can explain the incentives for national parties to join large European Political Groups instead of forming smaller nationalistic groupings. Empirical evidence shows increasing cohesion of European Political Groups and an increasing role of the European Parliament in EU inter-institutional decision making. As a consequence of this evolution, intergovernmentalism is being replaced with federalizing relations. The analysis can support positive expectations regarding the governability of the European Union after further enlargements provided that new member states have party systems fitting the European Political Groups.
\end{abstract}

JEL: C71, D72. H77

Keywords: Political parties, Coalitions, Power indices, Political institutions, European Union.

Address:

Prof. Josep M. Colomer. Universitat Pompeu Fabra, Department of Economics. Ramon Trias Fargas 25. Barcelona 08005 Spain.

e-mail: josep.colomer@econ.upf.es 


\section{$\underline{\text { 1. Introduction }}$}

The evolution of the European Community (EC) and the European Union (EU) demonstrates that not only formal institutions, but also organizations, such as political parties, can play an aggregating role, rendering institutional decision-making feasible in a pluralistic community. In the long run, political parties tend to adapt the institutional framework to their own Eplay ${ }^{1}$, in other words, to transform patterns of behavior into formal rules.

The basic model which can cast light on the EU's development in this respect runs as follows. When the initially established regulatory institutional framework is relatively loose, parties choose certain strategies and informal rules of behavior that shape their relations and produce collective outcomes. These patterns of behavior tend to become more formal and constraining institutional rules through incremental changes of the existing institutions. In this process, the aggregating role of political parties is extended to the institutional framework, which makes decision-making more regular and more predictable. (For basic concepts here applied, North, 1990).

The institutional development of the EC/EU can be approached with three different models, involving different roles of actors and parties, which can be called, respectively, Eintergovernmental ${ }^{1}$, Eimperial ${ }^{1}$, and Efederal $^{1}$. The intergovernmental model was dominant from the foundation of the European Ecomic Community in 1957 until mid 1980s. The institutional relations corresponding to this model are those of an international or diplomatic organization. The main actors are the governments of member-states. The Council of the European Union (formerly called Council of Ministers) appears to be the central institution, as it is formed by representatives of the governments of the member-states. As they consider themselves to be sovereign, the member-states have veto power on collective decisions, which means that most decisions are made by unanimity. Similarly, the European Council, consisting of the $\mathrm{EU}^{1} \mathrm{~s}$ Heads of State or Government, generally acts on the basis of unanimity.

After an initial period of innovative decisions in favor of a common market, during the 1960s ans 1970s, unanimity rule proved to be highly ineffective in making decisions, especially after successive enlargements of the EC from six to twelve member states. A single member's veto (as was frequently the case of French governments led by Gen. De Gaulle, British governments led by Margaret Thatcher, and others) was able to paralyze any initiative. Unanimity rule in the Council led to a period of stagnation, CEErosclerosis ${ }^{1}$ and EEuropessimism ${ }^{1}$, as it was called in the early 1980s. In reaction to incresingly pervading sclerosis, the EC accepted that certain decisions could be made by qualified majorities and subsequently enforced only by a subset of member-states. This model has been called Ereinforced cooperation ${ }^{1}$ or Ecloser cooperation ${ }^{1}$, as well as Evariable geometry ${ }^{1}$, Econcentric circles ${ }^{1}$, Estrong core ${ }^{1}$, Etwo speeds $^{1}$, Eà la carte ${ }^{1}$, Eflexible $^{1}$, and other interesting metaphors. I suggest that it should be called Eimperial ${ }^{1}$ because it corresponds to formulas used in classical empires, including, for instance, the German-Roman Empire or Austria-Hungary. Each unit implements a particular set of enforcing decisions. For example, the social chapter of the European Community was approved without the United Kingdom, the euro was initially accepted by only 11 out of the 15 member-states, the Schengen agreement on borders control affects a different subset of countries, etc. The main weakness of this model is that always creates the opportunity for every member-state to undertake its own decisions on commmon matters and withdraw from some Europe-wide developments.

The third, federal model includes the principle of territorial representation, as the other two models previously sketched, but it is more effective in decision-making because it is not based 
upon unanimity rule (in contrast to the intergovernmental model) and makes enforceable decisions for all countries (in contrast to the imperial model). The deployment of the federal model would require certain changes in inter-institutional relations. This should include in particular an increase in the legal powers of the European Parliament in order to cover the socalled Edemocratic deficit ${ }^{1}$, in other words, the relative limited role traditionally played by the only directly elected European institution. Political parties are the main actors able to make decision-making in the European Parliament feasible and, by this way, foster federalizing interinstitutional relations.

If the typical formula of a federal state were to be adopted, representatives of the people of the EU at large would share decision power with representatives of the territorial units. The European Parliament, which is elected directly by universal suffrage in a more or less simultaneous election and is internally organized in large European Political Groups, should be considered to be the lower chamber, the representative institution of the European citizens.

The Council, which represents the citizens of each country through the institutions of each member-state and tends to work on the basis of country ${ }^{1} \mathrm{~s}$ interests rather than on strict ideological positions, should be considered an upper chamber of territorial representation. A further improvement could give the Council as many representatives per member-state as votes. Both chambers, the Parliament and the Council, should have significant legislative and mutual veto powers. The Parliament and the Council are elected separately and with different rules. This usually produces the possibility that different political party majorities can be formed in each chamber. As a result, EU inter-institutional decisions have to be based on very broad agreements encompassing two different majorities, which is also a common formal feature of several federal states with symmetrical bicameralism (such as Germany).

In this framework, the European Commission should be considered to constitute the EU's executive (including, for instance, the Eminister ${ }^{1}$ in charge of the Common Foreign and Security Policy, now depending on the Council). Accordingly, the Commission would be appointed by, and made accountable to, the two parliamentary chambers. It would then rely on a large consensual supermajority, which would not be very different from the one which was obtained with the intergovernmental procedures. Some fears of CEungovernability ${ }^{1}$ of the EU have been expressed in the face of the possibility to move towards more innovative federal formulas. Yet, as suggested here, the federal model could actually maintain some of the consensual features that have traditionally characterized the working of the EC/EU's institutions, but with higher effectiveness.

As a matter of fact, the decision powers of the European Parliament have increased as a result of a series of incremental institutional reforms. The European Parliament was required only to be Econsulted ${ }^{1}$ by the Council according to the Rome Treaty (1957). Significant changes began after the first direct elections for in 1979. Further stages include the introduction of new rules forcing the Council to share certain legislation powers with the Parliament or co-operation procedure, as embodied in the Single European Act (1986), the co-decision procedure for legislative acts, as well as the formal requirement of the Parliament ${ }^{1}$ s support for the appointment of the Commission President, as introduced by the Maastricht Treaty on the European Union (1992), and the virtual replacement of the co-operation procedure with co-decision rules for most policy areas, as well as the requirement of a formal investiture of the Commission and its President by the Parliament prior to the Commissioners taking office, as introduced by the Amsterdam Treaty (1997) and enforced from 1999 on.

This article sustains that these changes would not have been able to give effective capability of 
decision-making to the highly pluralistic EU in the late 1980s and the 1990s if they had not been responded with aggregating initiatives by political parties. Political parties in the European Parliament benefit from the opportunities and incentives given by the existing institutional rules at any given moment. Accordingly, they have developed more cooperative and aggregative strategies in order to gain influence in the inter-institutional process. But, at the same time, political parties create these opportunities by promoting treaties and constitutional-like regulations that replace the dominant role of the Council with more complex formulas. Political party formation and coalition building in the European Parliament is being a driving force that makes the governance of the highly pluralistic European Union relatively effective and consensual. Electoral parties in the European Parliament have been involved in a long process of forming large Political Groups of increasingly Europe-wide scope. They have also developed continuous activities of majority coalition formation, in both processes of voting and the appointment of office holders. In spite of the fact that some national parties have been hesitant to participate in these processes and the developments have tended to be slow, gradual changes have rendered inter-institutional decision-making in the EU feasible and increasingly effective.

Multinational European Political Groups and multiparty parliamentary coalitions create intermediate aggregation mechanisms between highly pluralistic political and territorial representation and European-level decision-making. By this, the Parliament has been able to become an active partner in the inter-institutional process and to create federalizing links with the other institutions. In other words, political party strategies fill the gap that is left by loose institutional regulations and constraints and make EU inter-institutional relations relatively tight and effective.

The plan of the paper is as follows. The second section analyzes the formation of European Political Groups in the European Parliament from the time of the first direct election in 1979 to the fifth EP election in 1999. Section three applies certain models of coalition formation and distribution of voting power to measuring the power of European Political Groups in forming multiparty coalitions in the European Parliament. Section four discusses the dilemma faced by certain parties between trying to lead a small Group within the Parliament or to join a larger, more influential Group. The analysis of voting power both of European Political Groups in the Parliament and of national parties within the European Political Groups shows the incentives for national parties to favor aggregation in decision-making. Section five provides some empirical evidence on the increasing role of the European Parliament in EU inter-institutional decision making. Section six concludes with an evaluation and some positive expectations with respect to the governability of the European Union and its further evolution in the direction of a more federal system.

\section{Party Formation in the European Parliament}

Successive enlargements of the EC/EU have led not only to an increasing number of member states, but also to more political parties obtaining representation in the EU institutions. The members of the Council and of the European Parliament (as well as most Commissioners) are members of political parties which have run separately in national and in European elections respectively.

No Europe-wide significant aggregation is developed at the stage of forming electoral 
candidacies for the European Parliament. Electoral rules in the EU's member states vary considerably. All of them are now based on the principle of proportional representation, but electoral formulas and ballot procedures differ for each member. Candidacies, the selection of issues and campaign strategies are primarily conducted in a national framework. The European Parliament's elections, which have been termed Esecond-order national elections ${ }^{1}$, appear to have more of a character of national CEmidterms ${ }^{1}$ than of true European events (Reif, 1985; Marsh, 1998).

Up to more than one hundred different political parties have obtained representation at once in the European Parliament. Such a high level of party fragmentation might make inter-institutional decision procedures very ineffective and contribute to preserving the basic features of the $\mathrm{EU}^{1} \mathrm{~s}$ Eintergovernmental ${ }^{1}$ model. Yet, interestingly, enlargements and the corresponding increase in the number of parties obtaining representation in the European Parliament have not caused a growth in the total number of European Political Groups (EPGs). On the contrary, the number of EPGs has decreased after the two most recent elections, in 1994 and 1999.

Remarkably, the effective number of EPGs has decreased steadily since the first election to the European Parliament in 1979. The Eeffective number ${ }^{1}$ takes into account the relative size of each party, by this way measuring the degree of fragmentation of the party system (according to the formula of Laakso and Taagepera, 1979, as given in Table 1). In spite of representing 15 member states with their own political regimes and party systems, the European Parliament has a lower effective number of parties than the parliaments of several European countries, such as Belgium, Denmark, Finland, Italy, and the Netherlands.

The relatively small number of effective EPGs and the decrease of this number over time provide support for the interpretation that political parties have developed some effective strategies to reduce fragmentation and to form EPGs of an aggregating character. This trend has favored decision-making within the European Parliament and inter-institutional relations in the EU.

Table 1 provides an overview of the number of member states, national political parties, and European Political Groups, as well as the corresponding effective numbers by taking every unit's relative proportion of seats into account. As can be seen, both the absolute and the effective number of member states have considerably increased between 1979 and 1999. The absolute number of member states has passed from 9 to 15 . The effective number of member states, weighting for their size, has increased in accordance, from 6 to 9.5 (except for a small adjustment at the time of the German reunification, since it created a larger member state). The number of political parties obtaining representation in the European Parliament has also increased, from 41 in 1979 to 110 in the election of 1999. Yet the absolute number of European Political Groups, which increased twice during the first period, from 8 to 11, has decreased twice afterwards, from 11 to 9 . (The numbers are from 6 to 10 and then to 7 if the non-attached and independents ${ }^{1}$ groups are not counted). The effective number of European Political Groups, as weighted by their size and thus reflecting the degree of aggregation from an increasingly pluralistic setting of elected parties, has decreased from a value of 5.2 in 1979 (with a slight increase by 1984) to 4.0 in 1999.

Table 1 about here

EModerate ${ }^{1}$ parties have tended to prevail in the European Parliament. In all elections since 1979, the European Socialist Party and the Christian-Democrats or European People ${ }^{1}$ s Party 
together have gathered more than 50 percent of total number of seats. The Socialists and the Christians together have encompassed increasing proportions of seats with every election, from 54 percent in 1979 to 66 percent in 1999.

The smaller Group of the Liberals, always the third in number of seats, is usually placed in an intermediate position between the Socialist and the Christians when measured on a left-right ideological scale. Hence, a Econnected ${ }^{1}$ winning coalition could always be formed with the Socialists, the Liberals, and the People ${ }^{1}$ s party. This scheme based on these three Europeans Political Groups --the Socialists on the center-left, the smaller, intermediate Liberals in the center, and the Christians on the center-right-- closely resembles the domestic party structure in Germany, and it is not dissimilar to the distribution of parties in Belgium, the Netherlands, and Luxembourg.

Yet, significant parties from most of the other EU member states made the initial choice of forming their own European Political Groups, which produced a number of small Groups dominated by a single large national party (i.e., one that holds more than half of the seat total in the Group). This choice reflected the resistance of certain domestic-based parties formed in peculiar party-system configurations to adapt to the basic configuration of the party-system in the European Parliament previously described. As will be shown below, however, smaller Groups have moved toward aggregation into the two largest European Political Groups, the Socialist Party and the People ${ }^{1}$ s Party. (For the European Parliament and the European party systems, Gaffney, 1996; Morgan and Tame, 1996; Hix and Lord, 1997; Raunio, 1997; Corbett, Jacobs and Shackleton, 2000. For a comparative analysis of different national party-system Econfigurations $^{1}$, see Laver and Hunt, 1992. In contrast to the (EGerman ${ }^{1}$ or $^{2}$ EBenelux ${ }^{1}$ partysystem configuration alluded here, both the EAnglo ${ }^{1}$ and the EMediterranean ${ }^{1}$ configurations distinguished by the authors involve higher degrees of bipolarization and are characterized by more peculiar party ideological positions).

The formation of aggregative European Political Groups has followed different paces among the center-left and the center-right parties. In only two out of five elections, the set of center-left parties (those included in the Groups of Socialists, Rainbow, Greens, and Radicals) collectively obtained more seats than the set of center-right parties (those included in the Groups of Christian-Democrats, Conservatives, Democratic Alliance, Forza Europa and Europe of Nations). Yet, the Socialists were the largest European Political Group in the Parliament after the first four elections. The Socialist Party integrated national parties from all the member states since the first election in 1979 (with the exception of Ireland in 1984 when the Irish Labour failed to gain representation).

In contrast, the most integrative party on the center-right side of the spectrum, the People's Party, included national parties from only seven out of nine member states in 1979, while representatives from all member states were included only since 1989. In other words, while, for instance, the British Labour, the Central European and Nordic Social-democrats, and the Southern Socialists were integrated in the same European Political Group since the first direct election of the European Parliament, the British Conservatives, the Central European Christiandemocrats and other major center-right parties, such as the French Gaullists and Forza Italia, were in different European Political Groups for quite a long time. The Liberal Group and all other smaller Groups have never been based on representation from all member states. These trends are illustrated with figures regarding proportion of seats in Table 2. 


\section{$\underline{\text { 3. Parties, Coalitions and Power }}$}

In order to discuss (in the following section) the incentives for national parties to contribute to form aggregating EPGs, in this section I introduce some concepts on coalition formation and party bargaining and voting power. The type of coalition that parties tend to form depends on the institutional setting and the motives of the participating members. Basically, party motives are distinguished as office-seeking and policy or ideology-seeking. These motives introduce restrictions on the size of the coalition and on the policy-ideology position of the preferred partners, respectively. Four basic types of Eviable coalitions ${ }^{1}$ produced by different party motives can be distinguished: winning coalitions, WCs (no specific restrictions); minimal winning coalitions, MWCs (restriction on size); connected winning coalitions, CWCs (restriction on ideology); and minimal connected winning coalitions, MCWCs (restrictions on ideology and on size).

It can be expected that different institutional incentives will promote the formation of different types of coalition. WCs without restrictions can be found, for example, in international organizations, as well as in the EU Council, where the multidimensional issues submitted to collective decisions and the absence of offices to distribute among its members make rigid restrictions on the choice of partners irrelevant. MWCs are likely to be found in office elections in corporate bodies with no significant ideological cleavages. CWCs can be expected to correspond to ideologically oriented-parties in settings in which no offices are elected, such as multiparty Assemblies in presidential regimes, as well as the European Parliament. MCWCs correspond to ideologically-oriented parties in parliamentary regimes. When applied to a committee or a parliament, every model produces a different set of Eviable coalitions ${ }^{1}$. In order to measure the distribution of power for each party within every viable coalition, a general assumption is that only non-superfluous partners of the coalition can be considered to be Edecisive ${ }^{1}$ or powerful. (For more details on the approach followed in this article, see Colomer, 1996a, 1996b, 2000; Colomer and Hosli, 1997. Power indices and their appropriateness for the analysis of the EU institutions are discussed in Brams, 1975, 1985: 101-107; 1990; Hosli, 1995; Bruckner and Peters, 1996; Garret and Tsebelis, 1996; Nurmi, 1997; Felsenthal and Machover, 1998; and Symposium, 1999).

In the following sections, I use two models of coalition formation and the corresponding power indices on the basis of their appropriateness to measure political party power within the EU institutions. First, I analyze coalition formation among European Political Groups in the European Parliament from the assumption that the European Political Groups care about their relative ideological positions and form ideologically Econnected ${ }^{1}$ winning coalitions $(\mathrm{CWCs})$ between neighbor partners on the left-righ spectrum, in a similar way as has widely been assumed for the analysis of multiparty coalition formation in domestic parliaments, but they do not care about the size of the coalitions because, in contrast to domestic parliaments, they do not elect executive offices.

Second, the power of national parties within every European Political Group in the Parliament is measured on the assumption that, on the basis of sharing the same basic ideological allegiance (as happens, for example, among the members of the European Socialist Party, or among the members of the European People's Party, and so on), they form WCs without restrictions. When political parties form coalitions in the national Parliaments of most EU member states, 
their policy or ideology relative positions matter. A compelling, albeit informal rule of behavior is that parties tend to prefer close neighbors in the ideological space to more distant potential partners even if the latter could be sufficient in terms of their number of seats to form a majority coalition. This criterion of behavior reduces the set of viable winning coalitions and, as a result, public policy decisions tend to be more consistent. (For the analysis of coalition formation in European national parliaments with parliamentary regimes, see Laver and Schofield, 1990; Laver and Budge, 1992; Laver and Shepsle, 1996. For the analysis of coalition formation in Latin American assemblies with presidential regimes, Deheza, 1997, 1998).

The basic ideological affinities between the European Political Groups, as mentioned above, tend to be situated on the left-right axis, as is the case in most national parliaments. The relevance of the left-right dimension in the European Parliament and the location of the European Political Groups has been analyzed with empirical data, finding that ${ }^{3}$ coalitions form on the basis of ideology, not nationality ${ }^{2}$ (Kreppel and Tsebelis, 1996: p. 2; see also Laver, 1997; Kreppel, 1999; Hix, 1999, pp. 79-84; Corbett et al., 2000, pp. 90-93; well-established party positions on the left-right dimension for domestic parliaments can be found in Castles and Mair, 1984; Huber and Inglehart, 1995; Knutsen, 1998; a compilation in Appendix to Laver and Schofield, 1990).

Figure 1 about here

Figure 1 shows the relative positions of European Political Groups, as presented by the European Parliament itself. Five major party positions can be distinguished from left to right: (1) Left: the Communists in 1979 and 1984, and the Communist-dominated United and Nordic Left in 1989/United Left in 1994, as well as the European United Left (1989);

(2) Center-Left: the Groups formed by the Socialists in the five elections from 1979 to 1999 , the Rainbow in 1984 and 1989, the Greens since 1989, and the Radicals in 1994

(3) Center: the Liberals in the five elections;

(4) Center-Right: the Christian-democrats in the five elections, the Conservative Democrats in 1979, 1984 and 1989, the Gaullist Democratic Alliance in 1979, 1984, 1989 and 1994, Forza Europa in 1994, and Europe of Nations in 1994 and 1999;

and (5) Right: the Right in 1984 and 1989, Democracies and Diversities in 1999, as well as the Non-Attached in 1994 due to it rightist and nationalist composition.

In order to calculate the set of viable coalitions corresponding to the assumption that the European Political Groups maintain their ideological connection when they chose coalition partners, I assume that a coalition can be formed by Groups placed on contiguous positions in the policy space, for example, between the Socialist, the Liberal, and the People ${ }^{1} \mathrm{~s}$ Groups. We assume that Groups cannot form a coalition with a Group placed in a non-contiguous position without including all the Groups in the intermediate positions. For example, in the 1999 Parliament a coalition encompassing the United Left and the Liberals should also include the Socialists and the Greens. Similarly, a coalition including the Liberals and the rightist Democracies and Diversities should also have the People ${ }^{1} \mathrm{~s}$ and the Europe of Nations Groups as partners.

As mentioned, I assume that European Political Groups keep their ideological connection between the partners of the viable winning coalitions, but they do not necessarily care about the size of these coalitions. The latter assumption is realistic in this institutional context because the European Parliament does not elect or control a government and hence, the Groups cannot be 
office-seekers. Like ideological political parties acting in legislatures of non-parliamentary regimes, and in contrast to typical parliamentary regimes more frequently analyzed in the coalition formation literature, the European Political Groups are considered to be policy-seekers, restricting partnership in coalitions to their neighbors, but accepting the addition of numerically superfluous coalition partners.

On the basis of these criteria, I assume that European Political Groups in the European Parliament form connected winning coalitions (CWC), that is, coalitions of ideologically neighbor parties regardless of the size of the coalition. Within the set of viable CWCs, there is some variation depending on the subject matter. (Kreppel and Tsebelis, 1996; Hix and Lord, 1997, pp. 137-139; Kreppel, 1999).

Unpublished data for all 611 votes from July 1999 to March 2000 show that a center-left majority, including the Socialists and the Liberals as its core, is formed in 84 per cent of votes on civil liberties, foreign affairs and environment (the Greens join the majority on these issues in 78 per cent of votes). The majority built around the center by the Socialist, the Liberal and the People $^{1}$ s groups forms in 72 per cent of votes on constitutional, institutional, budgetary affairs, and fishery. Center-right coalitions based on the Liberal and the People ${ }^{1}$ s groups are also formed in 88 per cent of votes on economic affairs, industry, budget control and employment. (Author ${ }^{1} \mathrm{~s}$ calculations with data from Secretariat General ELDR, 2000).

More generally, in the European Parliament elected in 1999, it is possible to form 16 CWCs, of which 5 are MCWCs (those formed by: 1) United Left-Greens-Socialists-Liberals, with 328 seats; 2) Socialists-Liberals-People, with 463 seats; 3) Greens-Liberals-People, with 331 seats; 4) Liberals-People-Nations, with 313 seats; and 5) Liberals-People-Democracies \& Diversities, with 299 seats.) (The non-attached are not taken into account, in the assumption that their members may be added to any of these coalitions).

The corresponding power index is calculated by dividing the number of decisive partnerships of a European Political Group in the set of CWCs by the total of decisive partnerships for all parties. This calculation shows that 'center' players tend to gain in influence. When parties respect their ideological connectedness, the intermediate parties on the policy-ideology scale are advantaged. In particular, the party containing the median seat is a sure partner of any viable winning coalition. As a result, its relative bargaining power exceeds its proportion of seats (as well as its power if it is measured on the basis of an approach that abstracts from actors' policy or ideology motives).

Table 2 provides the values for the CWC, or Elegislative ${ }^{1}$, power index in the European Parliament. The comparison of these values with the proportions of seats held by the respective European Political Groups illustrates that the relative influence of parties in forming coalitions by bargaining and voting, as assessed on the basis of this power index, is highly favorable for the Liberals (which always contain the median seat), and about fair for the largest party, the Socialists in the first four elections and the People's Group in 1999, in the disadvantage of all the other Groups.

\section{The Dilemma of Political Parties}

Generally, political parties face a dilemma with respect to their mode of representation in the European Parliament. They can choose either to try to lead a small European Political Group, and hence be highly influential within this Group, or to join a larger European Political Group 
that is more influential in the Parliament, within which they may be, however, little influential. The rules for forming European Political Groups are rather permissive. According to 14th edition of the Rules of Procedure for the European Parliament enforced from May 1999 on, a European Political Group can be formed by 23 deputies if they come from two member states, or by 18 deputies if they come from three member states, or by 14 deputies if they come from four or more member states. Once the European Political Groups have formed, every Group makes decisions on the basis of a majority of its members. National party members are submitted to the internal voting discipline of the European Political Group to which they belong. (Attinà, 1990; Bowler et al., 1999; Corbett et al., 2000, pp. 89-90). Under the rather flexible requirements for forming European Political Groups in the five elections since 1979, only an average of 3.9 percent of the deputies has not been able to become a member of a European Political Group (and thus be forced to join the Group of the 'Non-Attached' or remain as independent). Incentives for national parties to either lead a small Group or join a larger Group can be assessed by comparing the relative voting power corresponding to either choice. For this purpose, I again resort to power index measurements. The power of a national party within the European Parliament can be approached by multiplying the ECWC index ${ }^{1}$ previously derived for a European Political Group in the European Parliament by the appropriate power index of the national party within the European Political Group. This will give us an estimation of the relative power of a national party in the European Parliament as it results from its belonging to a specific European Political Group.

In order to measure the power of the national parties within a European Political Group, I assume that any majority coalition of national parties can be formed within a European Political Group without significant restrictions. I assume that there are no significant ideological barriers between the political parties within a European Political Group because they share a common basic ideological position. Similarly, size should not be a relevant restriction, since the purpose of coalition-formation in this context is not the allocation of offices, but the establishment of a policy position of the respective European political Group in the European Parliament. Hence, the internal bargaining power of the political parties within the European Political Groups is here analyzed on the basis of the normalized Banzhaf power index. This is calculated by summing the decisive partnerships of a party by the total of decisive partnerships of all parties in the set of WCs.

By weighting the (Banzhaf) power index of a political party within its European Political Group with the (CWC or Elegislative ${ }^{1}$ ) power index of the European Political Group in the European Parliament, we obtain a measure of the power of the national party in the European Parliament. (For more details on calculation procedures and an illustration with the 1994 European Parliament, see Colomer and Hosli, 1997).

The global power of party $i$ in the European Parliament will be referred to as P(i). The values of this measurement appear to have been significantly different for the national parties on the center-left and for those on the center-right at different moments. This suggests an explanation for the different paces in the process of successive aggregation of national parties in powerful European Political Groups.

In summary, while the very large European Socialist Party was still enlarged with the Italian post-Communists and reunited up to 20 parties, the European People ${ }^{1}$ s Party was gradually enlarged with the members of previous small Groups led by the British Conservatives, the French Gaullists, and Forza Italia, among others.

Within the center-left, a rather strong degree of concentration into the European Socialist Party 
can be observed from the fist election in 1979. After the election of 1989, the Italian Communists (PCI), the largest party on the left side of the policy spectrum in Italy at the time, left the European Communist Group and formed the European United Left, together with a few minor partners. Yet this resulted to have been only an intermediate step, since at the following election, in 1994, the Italian Communists, already transformed into the Party of Democratic Left (PDS), entered the European Socialist Party. Domestic political strategies can largely account for the ideological evolution of the PCI, which led to the corresponding realignment within the European Parliament. But the approach developed here can cast light on the advantages of the corresponding moves in the European Parliament, which, given its specific party-system configuration, might not necessarily be as beneficial for the party as those in domestic politics. The PCI was the dominant party within the European Communist Group in 1979 and 1984, as it had more than 50 per cent of the seats of the Group. Yet, the Group became decreasingly powerful within the European Parliament, as illustrated in Table 2. The relative power of the PCI in the Parliament, as estimated according to the procedure previously discussed (i.e, its power index within the European Communist Group multiplied by the power index of the Communist Group in the European Parliament), can be estimated with the following values: P(PCI): 6.2 in 1979; $\mathrm{P}(\mathrm{PCI}): 1.5$ in 1984; $\mathrm{P}(\mathrm{PCI}): 0.7$ in 1989; $\mathrm{P}(\mathrm{PDS}): 2.5$ in 1994. These values suggest that the PCI made an initial somewhat costly move by creating its own Group, the European United Left, in 1989, since it made it even less powerful than in its previous membership to the Communist Group. The corresponding loss, however, was minor in absolute terms, given the low relative power already attained by the Communist Group in the Parliament. Once in the European Socialist Party in 1994, the PCI, now PDS, was scarcely influential within its Group (the corresponding Banzhaf value is about 9 per cent). But by this way it obtained higher power, that is, more global influence within the Parliament, than in its previous grouping. In parallel, the power of the remaining European Communist Group was reduced to almost zero.

The evolution of political parties in forming European Political Groups has been more intricate within the center-right of the European Parliament. A long-term tendency to an increasing concentration in the People's Party can be identified. However, the incentives for every political party to enter the PP were not always immediately positive. Using the approach previously presented, we analyze the relative positions of three small European Political Groups in the center-right space: the Conservatives or Democratic Group, the Gaullists of Democratic Alliance, and Forza Europa. These Groups were formed at the initiative of major center-right parties in countries not fitting the German and Benelux configuration of party-system, together with minor parties or fractions. Most of them have held nationalistic positions and rather reluctant stands to further advances toward a closer union in Europe.

The Democratic Group was dominated by the British Conservatives, as they always had more than 50 per cent of the seats in the Group. The corresponding power values of the British Conservatives (Con) in the European Parliament were: $\mathrm{P}(\mathrm{Con})$ : 9.4 in 1979; $\mathrm{P}(\mathrm{Con})$ : 10.6 in 1984. The Spanish Popular Party provisionally joined the Democratic Group in 1987, after Spain entered the EC. The Democratic Group became then quite powerful, even obtaining the Presidency of the European Parliament in 1986-89. Yet at the following election in 1989 (the first one for the Spaniards), the Spanish Popular Party, faced with what still would be an absolute majority of Britons in the Group that would have nullified its power, moved to the European People's Party, where it obtained some positive influence. The British Conservatives, remaining in their own dominated Group, attained then lower power than in the previous two legislatures: $\mathrm{P}(\mathrm{Con}): 5.5$ in 1989. In 1992 the British Conservatives (followed by their previous Danish minor 
partner in the Democratic Group) moved into the European People's Party, in spite of significant policy and ideological differences in their traditional positions, including in regard to the EU further union and enlargement. Yet, the corresponding power value was $\mathrm{P}(\mathrm{Con}): 1.2$ in 1994, that is, a less powerful position than in its previous grouping. Although this loss was partly produced by the lower representation in seats of the British Conservatives in the Parliament of 1994 in comparison with the previous elections, the move to join the People ${ }^{1}$ s Party in itself did not produce clear advantages for them. This may have maintained the appeal of the European People's Party for further potential new partners rather uncertain.

The Group of Democratic Alliance was dominated by the French Gaullists (RPR), as they always had more than 50 per cent of the seats in the Group. The corresponding power values of the French Gaullists in the European Parliament were: P(RPR): 0 in 1979; P(RPR) in 1984: 7.6.

Some French Liberal and Republican candidates who were included in the UDF coalition in domestic politics and had run separately from the Gaullists in previous elections to the European Parliament, ran together with them in 1989. Yet, they split into two Groups once in the Parliament. The new electoral partners returned to the European Liberal Group, while the Gaullists formed again their own-dominated group, Democratic Alliance. The corresponding power value was $\mathrm{P}(\mathrm{RPR})$ : 4.1 in 1989, that is, lower than in the previous occasion. At the following election in 1994, all the Christian-democrats, Republicans and Liberals forming the UDF and the Gaullists of the RPR ran together in a single candidacy with the commitment to remain in the same European Political Group after the election. Yet they split again, although this time a larger fraction of the previously coalesced candidates joined the European People ${ }^{1} \mathrm{~s}$ Party: 13 European deputies went to the People's Party, only one returned to the Liberal group, and 14 remained in the Democratic Alliance. In addition, an anti-EU candidacy was formed by ex-1/4members of the Gaullist party, obtaining 13 seats and the possibility to form their own European Group, Europe of Nations (which obtained a notable power in the European Parliament, $\mathrm{P}(\mathrm{EN})$ : 4.4 in 1994; $\mathrm{P}(\mathrm{EN}): 2.9$ in 1999). In spite of all of this, the Gaullists still retained some significant global power in the European Parliament, giving them incentives to maintain their own Group. The corresponding power value was P(RPR): 6.1 in 1994.

The European Political Group Forza Europa was dominated by Forza Italia (FI), the new centerright party formed in the early 1990s after the crisis of the Italian Christian-democrats in domestic politics. FI became a national government party in 1994 and, on the basis of its relative success in the European Parliament election of that year, it formed its own European Group. The corresponding power value of Forza Italia in the European Parliament was P(FI): 5.7 in 1994. During the 1994 legislature FI merged with the French Gaullists in the Democratic Alliance Group, forming the new European Political Group Union for Europe. While the RPR had dominated the Democratic Alliance Group, as illustrated before, FI obtained a very influential position within the new Group at the expense of the RPR. The corresponding power values in the Parliament were: P(FI): 12.7 in 1995; P(RPR): 0.8 in 1995.

The European People ${ }^{1}$ s Party has, thus, not only gathered together Christian-democratic parties from nine countries (Belgium, France, Germany, Greece, Ireland, Italy, Luxembourg, the Netherlands, as well as the Catalan and Basque nationalists). It has gradually integrated other national parties, including the Conservatives from Britain and Denmark having previously formed a separate Group, and the Spanish Popular Party who had provisionally joined the latter. The number of French seats in the European people's Party has also increased. Initially, the fragmentation of the French center-right worked against the Group, whose French membership went from nine in 1979 to eight in 1984 and six in 1991 (at the advantage of the Liberal Group 
and the Democratic Alliance). Yet during the 1989 legislature the People's Party welcomed four French members of the Liberal Group (led by the former president of the Group) and one from the Democratic Alliance, gathering together eleven at the end of the period, and then increased its number to thirteen after the 1994 election.

A minor Portuguese party, the CDS, left the People's Party after the 1994 election on the basis of its anti-EU stands. Yet the major center-right Portuguese party, the PSD, previously in the Liberal Group, moved to the People's Party during the 1994 legislature, thus globally increasing also the Portuguese membership in the Group.

Shortly before the end of the 1994 legislature, Forza Italia joined the People ${ }^{1}$ s Party and tried to persuade its Gaulllist former partner in the Union for Europe Group to do the same. The French finally did it after the election of 1999, obtaining the symbolic concession of renaming the Group as EEuropean People ${ }^{1}$ s Party (Christian-Democrats)/European Democrats ${ }^{1}$. The corresponding power value of the new French component of the People's Party is P(RPR): 2.9, in 1999, thus making their move into the more aggregative People ${ }^{1} \mathrm{~s}$ Party positively rewarding. These moves suggest that the process of forming an encompassing European Political Group within the center-right space in the European Parliament by the gradual enlargement of the People ${ }^{1}$ s Party has been a relatively costly process. Some national parties having previously formed their own dominated, small Groups had to accept temporary sacrifices in the expectation to obtain similar moves from other parties to enhance the global power of the People ${ }^{1}$ s Party. Observers have noted that the degree of internal ideological homogeneity of the Group has somewhat diminished with successive integration of new parties in it, with some tensions developing between Christian-democrats and more Conservative partners. But, in the long-term, aggregation within the center-right cluster of the European Parliament has been as effective as the aggregation in the Socialist Party, not only in terms of relative proportion of seats, but, according to our analysis, also with respect to bargaining and voting power in order to form majority coalitions in the European Parliament.

Actually, some degree of initial heterogeneity is essential in any aggregation process. The formation of increasingly large, aggregative European Political Groups in the European Union during the late 20th century can be compared to certain processes of forming electoral and parliamentary nation-wide political parties in West European countries during the late 19th and early 20th centuries (including, among others, Britain, France, Germany, and Spain). Political representatives of the time were strongly rooted in local constituencies, they promoted local interests with no clear priorities on national issues, and many of them held vague ideological positions. The parallel can be extended to the fact that some domestic parliaments at the time were relatively weak in making the executive accountable (especially in certain monarchies). But the aggregation of local representatives in national parties created higher policy and ideology homogeneity among political representatives while contributing to reinforce the role of parliaments, in a comparable way as the aggregation of national representatives into European Political Groups is now promoting more effective decision making and contributes to giving the European Parliament more institutional strength. To the extent that national parties are submitted to majority decisions within large European Political Groups and to the Group ${ }^{1}$ s voting discipline in the Parliament, nationalistic positions against an ever closer union obtain lower prominence in the institutional process.

\section{The Increasing Role of the European Parliament}


According to the assumptions and expectations previously developed, empirical evidence shows remarkably high and increasing degrees of parliamentarians ${ }^{1}$ participation and internal cohesion of the European Political Groups in the European Parliament.

Participation of individual members of the European Parliament in voting sessions has increased from about 48 per cent in 1989-94 to 61 per cent in 1994-99 and to 72 per cent in 1999-2000. In the Parliament elected in 1999, the highest levels of attendance correspond to the largest Groups, the People ${ }^{1}$ s, the Socialists, the Liberals and the Greens, all of them above the average, with values between 73 and 77 per cent. (Raunio, 1997; and Author ${ }^{1}$ s recalculations for individual members average from Hix and Lord, 1997, p. 135, and from unpublished data in Secretariat General ELDR, 2000).

Internal cohesion of the European Political Groups has also increased steadily at successive legislative periods. On the basis of analysis of Roll Call votes, Table 3 shows the average proportions of individual members of the Parliament voting in accordance to their European Political Group. As can be seen, internal cohesion rises over time: from 74 per cent in 1984-89 to 84 per cent in 1989-94, 88 per cent in 1994-99, and 90 per cent in 1999-2000. Specifically, the largest Groups, the People ${ }^{1} \mathrm{~s}$, the Socialists, the Liberals and the Greens, have reached the highest degrees of discipline in voting, between 90 and 95 per cent in the Parliament elected in 1999. Internal cohesion of European Political Groups in the European Parliament is certainly higher than that of political parties in the United States Congress.

These striking results contradict conventional assumptions that the larger the European Political Groups and the higher the number of their national components, the less cohesive they would tend to be. In contrast, as larger Groups have higher chances of being decisive in the Parliament, as discussed previously, decisiveness increases the incentives for individual members to participate and to vote as a block.

Table 3 about here

As previously suggested, the aggregation of national parties in large aggregative European Political Groups, their internal cohesion, and their choice of ideologically close partners in forming majority coalitions, make decision-making in the European Parliament feasible. By becoming more effective in decision-making, the European Parliament is able to play a more significant role in inter-institutional relations. There is ample empirical evidence showing an increasing degree of influence of the European Parliament in EU inter-institutional processes, as can be observed for the Parliament's role in legislative activity, in budget approvals, and in its control on the European Commission.

First, the introduction of the co-decision procedure, which permits a decision to be made with the support of only a qualified majority of the Council together with the majority of the Parliament, has increased the volume of legislation. An annual average of 55 legislative acts were approved by the co-operation procedure, in an overwhelming proportion by the Council unanimity, during the period 1987-1993. In contrast, an annual average of 49 legislative acts by co-operation and 26 by co-decision --so, a total of 75 legislative acts per year-- were approved during the period 1993-1998. In other words, the co-decision procedure has been used in about 35 percent of the total legislative activity of the EU from its introduction in 1993 to 1998. (Author ${ }^{1}$ s own calculation with data from European Parliament 1994, 1997, 1998).

This is consistent with the claim that ${ }^{3}$ under the Amsterdam treaty ${ }^{1}$ s version of the co-decision 
procedure, the Parliament is a co-equal legislator with the Council, whereas the Commission ${ }^{1} \mathrm{~s}$ influence is likely to be more informal than formal ${ }^{2}$. (Tsebelis and Garret, 1999; 3). Empirical analysis also based upon the data published by the European Parliament shows that ${ }^{3}$ on the aggregate there is a higher success rate of parliamentary amendments under codecision than under cooperation ${ }^{2}$. (Tsebelis et al. 1999; 3).

Second, the role of the European Parliament in the elaboration and approval of the EU budget has become increasingly relevant. During the early years of the Community, from 1958 to 1974, the Parliament had no real budgetary powers. From 1975 on, the Council and the Parliament developed frequent conflicts regarding the classification of expenditures between Ecompulsory ${ }^{1}$ (as such expenditure necessarily derived from the EU treaties, according to the Council interpretation) and Enoncompulsory ${ }^{1}$ (which initially concerned only administrative expenditure). By this way, the Council reserved for itself exclusive Ecompetences ${ }^{1}$ on agriculture and certain international agreements, which amounted to the bulk of the EU budget. At the requirement of the Parliament, the European Court of Justice judged the 1986 budget calling upon the two institutions to reach an agreement. More cooperative decisions were fostered by the Inter-institutional Agreement on budgetary discipline and improvement of the procedure signed in 1988, which led to the approval of the financial framework for the period 1994-99. In 1995, on the basis of the lack of agreement with the Council, the President of the European Parliament declared the final adoption of the EU budget unilaterally, although a new decision of the Court of Justice forced to resume the previous procedure. Inter-institutional cooperation between the Council and the Parliament led to the approval of the EU financial Agenda 2000-2006 in May, 1999. (From data in European Parliament, 1996, and press). Finally, the European Parliament provoked the resignation of the whole European Commission, including its President, after voting a motion of censure and threatening with further initiatives of control in March, 1999. Interestingly, successive motions of censure on the Commission by the Parliament had obtained increasing number of favorable votes: 16 in June 1990, 8 in July 1991, 96 in December 1992, 118 in February 1997, and 232 in January 1999. The latter was still short of a majority, but the credible threat that a new voting could obtain larger support precipitated the resignation of the Commissioners a few weeks later. Similarly, votes of confidence on incoming Commissions have obtained increasing numbers of negative votes: 31 in February 1981 (Thorn Commission), 34 in January 1985, not recorded in January 1989, 84 in January 1993 (on the three Delors Commissions), 104 in January 1995 (Santer Commission), and 138 and 153 in September 1999 (Prodi Commission). (Corbett et al., 2000: 236, 245).

\section{Conclusion}

The evolution of the institutions of the European Union shows that the role of political parties in rendering institutional decision-making feasible in a pluralistic community can be crucial. European political parties have played an aggregating role within a loose institutional framework that initially allowed mere EEintergovernmental ${ }^{1}$ relations to develop. Aggregating initiatives from a highly fragmented set of national political parties in order to form larger European Political Groups, as well as majority coalitions among these Groups in the European Parliament, fill the gap left by relatively low constraining institutional rules. The corresponding success in decision-making helps the institutions themselves to become more consistent and effective. To the extent that the European Parliament was highly fragmented, the Council, making 
decisions by unanimity, could remain the dominant institution of the EU. The basic features of the intergovernmental model were maintained, but this led the EC to a long period of paralysis or CEEurosclerosis ${ }^{1}$, as was called in the 1970 s and early 1980 s, provoked by the opportunities given to some individual national governments, as represented in the Council, of vetoing further measures of European integration and union.

To the extent that the formation of European Political Groups and multiparty coalitions makes decisions in the European Parliament relatively easier, inter-institutional relations corresponding to the federal model for the European Union are fostered. Decision-making becomes more effective not only regarding public policies, but also regarding treaties and constitutional-like regulations, so reinforcing the tightness of the institutional framework and the role of the Parliament in it. As nationalistic groupings are replaced by larger European Political Groups in which every national party is submitted to the Group discipline, further decisions toward a closer union can be made with less nationalistic resistance. In contrast to previous periods of CEEuropessimism $^{1}$, new treaties and major decisions have been approved in the 1990s with increasing frequency, including a new enlargement up to 15 member states and the creation of a new common currency (the euro).

From the perspective developed here, further enlargements of the EU may be challenged not only by factors traditionally considered being relevant, such as major differences between countries in economic structures or in public policy, but also by a low degree of fitness of new members ${ }^{1}$ party-systems. New candidates to become member states of the EU could facilitate the governance of a highly pluralistic Europe by adapting their political representation to the patterns already developed within the EU institutions, especially in regard to the configuration of European Political Groups.

The analysis here presented shows that Europe-wide political party building, id eologically consistent coalition formation, and an ever closer Union advance together and mutually reinforce each other.

\section{References}

Attinà, Fulvio. 1990. EThe Voting Behavior of the European Parliament Members and the Problem of Europarties ${ }^{1}$, European Journal of Political Research, 8, 557-79.

Balinski, Michel L., and Svetlozar T. Rachev. 1997. CERounding Proportions: Methods of Rounding ${ }^{1}$, Mathematical Scientist, 22, 1-26.

Bowler, Shaun, David M. Farrell, and Richard Katz. 1999. Party Discipline and Parliamentary Government. Columbus: Ohio State University Press.

Brams, Steven J. 1975. Game Theory and Politics. New York: Free Press. -- 1985. Rational Politics. Decisions, Games, and Strategy. Washington: Congressional Quarterly Press.

-- 1990. Negotiation Games. Applying Game Theory to Bargaining and Arbitration. New York: Routledge.

Bruckner, Matthias, and Torsten Peters. 1996. EResearch Note: Further Evidence on EU Voting Power ${ }^{1}$, Journal of Theoretical Politics, 8, 3, 31721. 
Castles, Francis and Peter Mair. 1984. ELeft-Right Political Scales ${ }^{1}$, European Journal of Political Research, 12, 83-8.

Colomer, Josep M. 1996a. EMeasuring Parliamentary Deviation ${ }^{1}$, European

Journal of Political Research, 30, 1, 87-101.

-- 1996b. Political Institutions in Europe. London and New York: Routledge.

-- 2000. Political Institutions. Social Choice and Democracy. Oxford: Oxford University Press.

Colomer, Josep M., and Madeleine O. Hosli. 1997. EDecision-Making in the

European Union: The Power of Political Parties ${ }^{1}$, Aussenwirtschaft, 52,

255-80.

Corbett, Richard, Francis Jacobs, and Michael Shackleton. 2000. The

European Parliament. London: John Harper.

Deheza, Grace Ivana. 1997. Coalition Cabinets in Presidential Systems: South

America. Doctoral dissertation. Florence: European University Institute.

-- 1998. EGobiernos de coalición en el sistema presidencial: América del

Sur $^{1}$, in Dieter Nohlen and Mario Fernández eds. El presidencialismo

renovado: Institucionalismo y cambio político en América Latina.

Caracas: Nueva Sociedad, 151-169.

European Parliament. 1994. Les Avis Législatifs du Parlément Européen et

Leur Impact. Luxembourg: European Parliament, Direction General des

Études European Parliament.

-- 1996. Report on the Budgetary Procedure. Luxembourg: European

Parliament. European Parliament.

-- 1997. Progress Report 1 August 1996 to 31 July 1997. Luxembourg:

European Parliament, Conciliation Committee. European Parliament.

-- 1998. Progress Report 1 August 1997 to 31 July 1998. Luxembourg:

European Parliament, Conciliation Committee.

Felsenthal, Dan S., and Moshé Machover. 1998. The Measurement of Voting Power: Theory and Practice, Problems and Paradoxes. Cheltenham: Edward Elgar.

Gaffney, John ed. 1996. Political Parties and the European Union. London and New York:

Routledge.

Garrett, Geoffrey, and George Tsebelis. 1996. EAn Institutional Critique of

Intergovernmentalism ${ }^{1}$, International Organization, 50, 2, 269-99.

Hix, Simon. 1999. The Political System of the European Union. London: Macmillan.

Hix, Simon, and Christopher Lord. 1997. Political Parties in the European Parliament. London: Macmillan.

Hosli, Madeleine O. 1995. EThe Balance Between Small and Large: Effects of

Double-Majority System on Voting Power in the European Union ${ }^{1}$, International Studies Quarterly, 39, 351-70.

Hubber, John D., and Ronald Inglehart. 1995. EExpert Interpretations of Party Space and Party Locations in 42 Societies $^{1}$, Party Politics, 1: 73- 111.

Knutsen, Oddbjørn. 1998. CEExpert Judgements of the Left-Right Location of Political Parties:

A Comparative Longitudinal Study ${ }^{1}$, West European Politics, 21, 2: 63-94.

Kreppel, Amie. 1999. ERules, Ideology and Coalition Formation in the

European Parliament: Past, Prsent and Future' ${ }^{1}$ Paper to the Annual

meeting of the American Political Science Association, Atlanta, Ga.

Kreppel, Amie, and George Tsebelis. 1996. ECoalition Formation in the 
European Parliament ${ }^{1}$. Paper to the Annual meeting of the American

Political Science Association, San Francisco, Ca.

Laakso, Markku, and Rein Taagepera. 1979. EEffective Number of Parties: A

Measure with Application to West Europe', Comparative Political Studies, 12, 3-21.

Laver, Michael. 1997. EGovernment Formation in the European Parliament ${ }^{1}$.

Aussenwirtschaft, 52, 223-248.

Laver, Michael, and Ian Budge eds. 1992. Party Policy and Government

Coalition. London: Macmillan.

Laver, Michael, and W. Ben Hunt. 1992. Policy and Party Competition. L London and New

York: Routledge.

Laver, Michael, and Norman Schofield. 1990. Multiparty Government: The

Politics of Coalition in Europe. Oxford: Oxford University Press.

Laver, Michael, and Kenneth A. Shepsle. 1996. Making and Breaking

Governments: Cabinets and Legislatures in Parliamentary Democracies.

Cambridge: Cambridge University Press.

Marsh, Michael. 1998. EETesting the Second-Order Election Model after Four

European elections ${ }^{1}$, British Journal of Political Science, 28, 591-607. Morgan, Roger, and Clare

Tame eds. 1996. Parliaments and Parties, The

European Parliament and the Political Life in Europe. London: Macmillan.

North, Douglass C. 1990. Institutions, Institutional Change, and Economic

Performance. Cambridge: Cambridge University Press.

Nurmi, Hannu. 1997. EThe Representation of Votes Groups in the European Parliament: a Penrose-Banzhaf Index Analysis ${ }^{1}$, Electoral Studies, 16, 3, 317-327.

Raunio, Tapio. 1996. Party Group Behaviour in the European Parliament. Tampere: Acta

Universitatis Tamperensis, A 521.

-- 1997. The European Perspective: Transnational Party Groups

in the 1989-1994 European Parliament. Ashgate: Brookfield.

Reif, Karlheinz ed. 1985. Ten European Elections. Aldershot: Gower.

Secretariat General, European Liberal, Democratic and Reformist Group (ELDR). 2000.

Internal Report. Brussels: EP ms.

ESymposium: Power Indices and the European Union ${ }^{1}$, Journal of Theoretical

Politics, 11, 3 .

Tsebelis, George, and Geoffrey Garrett. 1999. ELegislative Politics in the

European Union'. UCLA ms.

Tsebelis, George, Christian B. Jensen, Anastassios Kalandrakis, and Amie

Kreppel. 1999. ELegislative Procedures in the European Union: An

Empirical Analysis ${ }^{1}$. UCLA ms.

Note

I am very grateful to the Patronat Català Pro-Europa and MEP Carles Gasòliba for inviting me to visit the European Parliament in Brussels, as well as to Bo Manderup Jensen, Secretary General of the ELDR Group, Frank A. Wall, Council ${ }^{1}$ s Director of Parliamentary and Institutional Affairs, and Jaume Duch, from the Directorate General for the Press, for information and unpublished data. Previous drafts of this paper were presented at conferences of the NEMEU project in Prague and the American Political Science Association in Atlanta, both in 1999; I acknowledge help and useful suggestions received from the organizers and participants, especially Madeleine Hosli, Bernard Steunenberg, and John Smith. 
Table 1. Fragmentation of the European Union (1979-1999)

Election year: 19791984198919941999

$\begin{array}{llllll}\text { Member-states } \quad 9 & 10 & 12 & 12 & 15\end{array}$

Effective no. $\quad 6.0 \quad 6.6 \quad 8.2 \quad 8.1 \quad 9.5$

Political parties 41467095110

European Political Groups $89911 \quad 10 \quad 9$

Effective no. $\quad 5.2 \quad 5.3 \quad 5.0 \quad 4.6 \quad 4.0$

Note: Data correspond to the initial composition of the European Parliament after every election. The Eeffective number ${ }^{1}(\mathrm{~N})$ reflects the number and the relative size of the units represented; it is calculated according to the formula $\mathrm{N}=1 / \ldots$ pi2, where $\mathrm{p}$ is the proportion of seats of member-state, party or group $i$.

Table 2. Seats and Voting Power of European Political Groups (1979-1999)

Election year: $1979198419891994 \quad 1999$

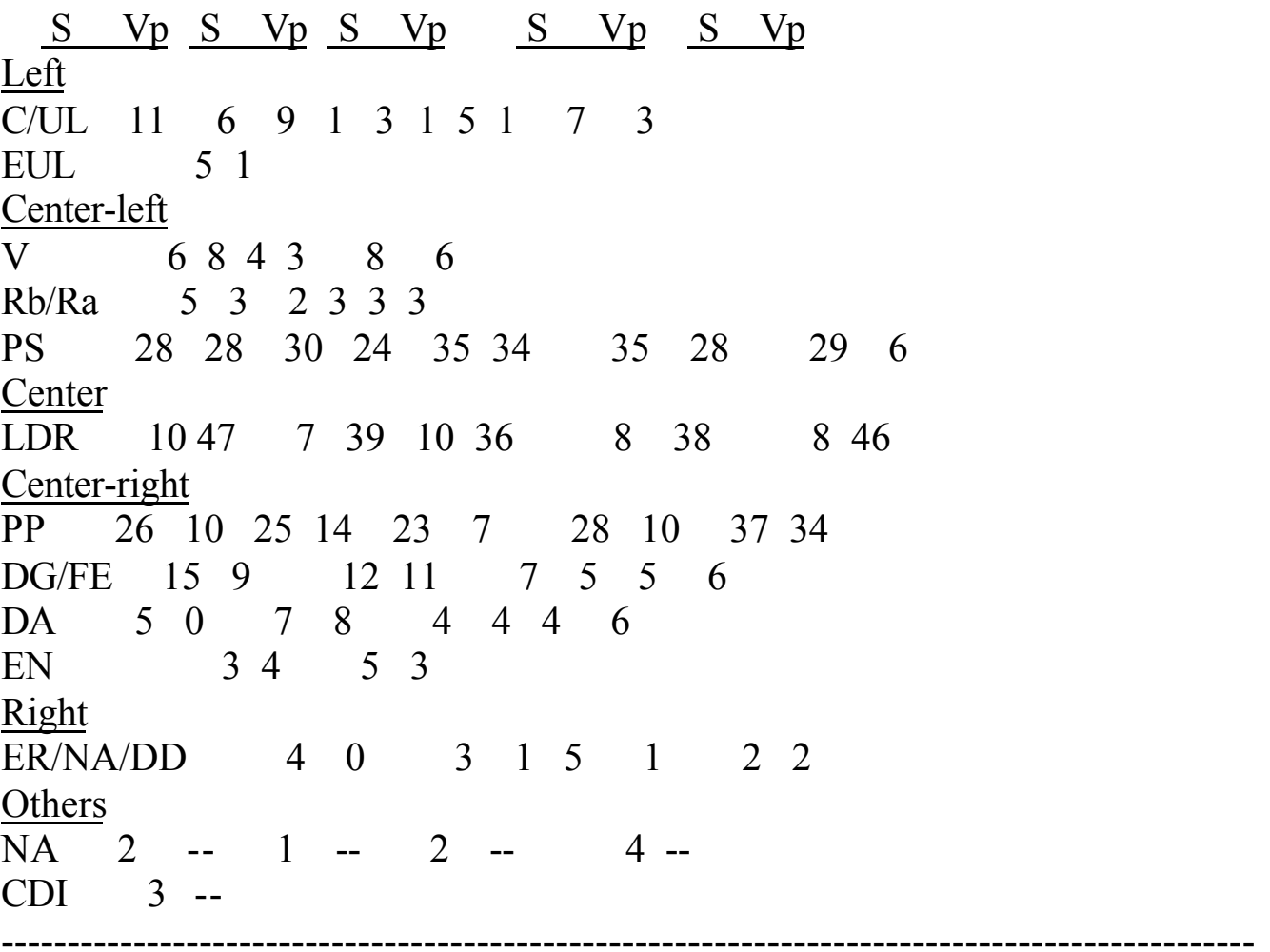

Total: $100 \quad 100100100 \quad 100 \quad 100 \quad 100 \quad 100 \quad 100100$

Note: S: proportion of seats; Vp: voting power (in forming connected winning coalitions, CWC). Numbers are rounded by the method of greatest remainders, according to rules by Balinski and 
Rachev (1997).

Left: C/LU/UL: Communists (1979, 1984)/United and Nordic Left (1989, 1994, 1999); EUL: European United Left (1989).

Center-left: Rb/Ra: Rainbow (1984, 1989)/Radicals (1994); V: Greens (1989, 1994, 1999); PS:

Socialists (1979, 1984, 1989, 1994, 1999).

Center: LDR: Liberals (1979, 1984, 1989, 1994, 1999).

Center-right: PP: Christians (1979, 1984, 1989, 1994, 1999; DG: Conservatives (1979, 1984, 1989); FE: Forza Europa (1994); DA: Democratic Alliance (1979, 1984, 1989, 1994); EN:

Europe of Nations (1994, 1999).

Right: ER/NA: European Rigth (1984, 1989), Non-Attached (1994); DD: Democracies and Diversities (1999).

Others: NA: Non-Attached (1979, 1984, 1989, 1999; CDI: Coordination Defense of Independents (1979).

Table 3. Voting Cohesion of European Political Groups (1984-2004)

Election year: 1984198919941999

AVERAGE: $74 \quad 84 \quad 88 \quad 90$

$\underline{\text { Left }}$

$\begin{array}{lllll}\text { C/UL } & 71 & 93 & 84 & 84\end{array}$

EUL 94

Center-left

$\begin{array}{llll}\mathrm{V} & 88 & 85 & 94\end{array}$

$\begin{array}{llll}\mathrm{Rb} / \mathrm{Ra} & 68 & 70 \quad 100\end{array}$

$\begin{array}{lllll}\text { PS } & 62 & 79 & 89 & 92\end{array}$

Center

$\begin{array}{lllll}\text { LDR } & 70 & 86 & 80 & 95\end{array}$

Center-right

\begin{tabular}{lllll}
\hline $\mathrm{PP}$ & 84 & 88 & 90 & 90
\end{tabular}

DG/FE $\quad 83 \quad 92 \quad 81$

DA $\quad \begin{array}{lll}76 & 65 & 93\end{array}$

$\begin{array}{lll}\text { EN } & 71 \quad 83\end{array}$

$\underline{\text { Right }}$

$\overline{\mathrm{ER} / \mathrm{NA} / \mathrm{DD}} \quad 96 \quad 100 \quad 68$

Note: Internal cohesion of European Political Groups (EPGs) is measured on the basis of Roll Call votes. The averages at the top are percentages of all individual members of the European Parliament (excluding Non-Attached) having voted according to their EPG (these numbers are different from the Group averages given by the sources mentioned below). The other numbers are percentages of individual members of each EPG voting as a block.

Party full names and rules for rounding number as in Table 2.

Sources: For the periods starting in 1984, 1989, and 1994, adapted from calculations on samples of votes in Attinà (1990), Raumio (1996), and Hix and Lord (1997) and Hix (1999), respectively. 
For 1999-2000, author ${ }^{1}$ s calculations with unpublished data on all 611 votes from July 1999 to March 2000 from Secretariat General ELDR (2000). 